\title{
Internal Conflict Resolution between Government of Indonesia and Separatist Movement in Papua using Horse-Trading Mechanism
}

\author{
Sekar Wulan Febrianti ${ }^{1}$ (D), Ajeng Sekar Arum 1,* (D), \\ Windy Dermawan ${ }^{1}$ (D), and Akim ${ }^{1}$ \\ ${ }^{1}$ Department of International Relations, Faculty of Social and Political Sciences, \\ Padjadjaran University, 45363 West Java, Indonesia \\ * Corresponding Author: ajeng17001@mail.unpad.ac.id
}

\section{ARTICLE INFO}

Publication Info:

Literature Review

How to cite:

Febrianti, S. W., Arum, A. S.,

Dermawan, W., E Akim, A. (2019).

Internal Conflict Resolution Between

Government of Indonesia and

Separatist Movement in Papua using

Horse-Trading Mechanism. Society,

7(2), 83-100.

DOI : $10.33019 /$ society.v7i2.86

Copyright (C) 2019. Owned by Author(s), published by Society

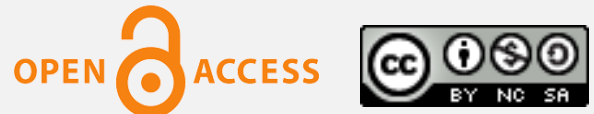

This is an open access article.

License: Attribution-

NonCommercial-ShareAlike

(CC BY-NC-SA)

Received: August 4, 2019;

Accepted: November 22, 2019;

Published: December 17, 2019;

\begin{abstract}
The study aims to analyze the process of internal conflict resolution between the Government of Indonesia and the separatist movement in Papua (Free Papua Movement (Indonesian: Organisasi Papua Merdeka or OPM)) using a horse-trading mechanism. This study was qualitative method by discussing the Free Papua Movement background and the conflict, then discussing the conflict process of timeline analysis tool to understand the development of its movement based on chronological order, and discussing the conflict resolutions that have been carried out with conflict mapping analysis tool to understand the actors that involved and their objectives. The conflict is the result of complexity among historical backgrounds, ideology, and a sense of injustice in Papua, on the other hand, the international community has increasingly supported Papua. Horse-trading has been used to resolve the conflict of Free Papua Movement and the Government of Indonesia, yet it has not yet reached a new resolution. The horse-trading mechanism effectively resolves the conflict when trust has been achieved between them to communicate both of them where they can deliver their objectives openly.
\end{abstract}

Keywords: Conflict; Horse-Trading Mechanism; Indonesia; OPM; Separatist

Copyright (C) 2019. Owned by Author(s), published by Society. This is an open-access article under CC-BY-NC-SA license.

https://doi.org/10.33019/society.v7i2.86 


\section{Introduction}

During the Republic of Indonesia became an independent nation-state, The Dutch government began preparing Papua for its independence to separate from both Dutch and Indonesia governments. The preparations were the formation of a Papuan legislative body, flag, and national anthem. However, the Government of Indonesia declared Papua as part of the republic in the New York Agreement in 1962 without any Papuan participation.

The Papuan educated class sought the right of freedom for Papuan to choose to separate from Indonesia and the Netherlands to the United Nations in 1964. Furthermore, its efforts developed to become more structured and formed the Free Papua Movement (Indonesian: Organisasi Papua Merdeka or OPM). The movement seeks to increase awareness and support from the world communities for Papuan independence efforts by the divisions consists of armed groups operating in three different regions, groups carrying protests and demonstrations, and the last group is based in abroad (Hadi, 2007). Quoted from the BBC Indonesia article (2018), OPM launched several armed resistance against civil society transmigrants from outside Papua, started on July 26, 1965 in Manokwari, and in 2018 there were several shootings of Trans Papua project workers, PT Istaka Karya workers, members of Indonesian Police Mobile Brigade Corps (known as Brimob), and detention of teachers and medical personnel.

Various resolutions of the Government of Indonesia to resolve the conflict have been carried out, ranging from repressive or militaristic to non-repressive measures such as the enactment of the Law of the Republic of Indonesia Number 21 of 2001 on Special Autonomy for the Papua Province.

Some previous studies and findings have contributed to knowledge about the conflict in Papua, as Sugiyanto (2017) and Sefriani (2003) with the international law approach, Sugandi (2008) with International Institutional as a mechanism for resolving the conflict. Suratman (2017) stated that the separatist movement in Papua has been one of the indicators for proxy war happening and becoming an unsolving problem in Indonesia. While Viartasiwi (2018) and Safitri (2012) focus on historical aspects that can be used to manipulate legitimation and political instruments in sectarian conflict between the Government of Indonesia and West Papuan nationalists. Hadi (2016) revealed that the struggle for Papuan independence has used nonviolence actions through technological uses and propaganda media to achieve their political objectives, namely to raise supports from international communities.

Other studies, Istikharoh (2017), the negotiator deployment to diplomacy dialogue of Government of Indonesia to free the Indonesians of the Abu Sayyaf group hostage resulted in success. Kamlian (2011), it is also used to resolve the separatist conflict of ethnic and religious backgrounds of the Moro conflict in the Philippines. The efforts of the Philippine Government were initially repressive at the end leading to negotiations that resulted in agreements that were agreed to by Moro people and the Government of the Philippine.

Until now the OPM conflict has not yet found a resolving point. The West Papua National Liberation Army - Free Papua Movement (Indonesian: Tentara Pembebasan Nasional Papua Barat Organisasi Papua Merdeka or TPNPB-OPM) continues to voice its interests for 'independence' from Indonesia and file a lawsuit against the Government of Indonesia. Forasmuch as TPNPB-OPM does not meet its demands, the organization will threaten that the war between OPM and the Government of Indonesia will not be ended.

Peter Wallensteen (2015) suggests seven mechanisms for conflict resolution. First, a party may change its goal, the second, the parties stick to their goals but find a point at which resources can be divided, the third, horse-trading, the fourth way shared control, the fifth, to

Copyright (C 2019. Owned by Author(s), published by Society. This is an open-access article under CC-BY-NC-SA license.

https://doi.org/10.33019/society.v7i2.86

84 
leave control to somebody else, the sixth, arbitration or other legal procedures, and the seventh, left to later or even to oblivion. This study discussed the horse-trading conflict resolution mechanism. The horse-trading mechanism is carried out with a compromise between the two sides, where one side has all of its demands met on one issue, while the other has all of its goals met on another issue. This mechanism results in a new decision after the two sides communicate to find a solution together, with the condition that both override each other's egoism. This conflict requires a good relationship between the conflicting parties. One party gets all their requests fulfilled on a problem, while the other party gets all their demands on another problem. This mechanism is different from compromise which sacrifices a portion of the demands of each party.

The horse-trading mechanism has opportunity to become an alternative resolving internal conflict in Papua compared to the other six Wallensteen mechanisms since it places each party's position in an open dialogue to deliver the demands of both parties as long as the demands are in the corridor or boundary that is possible for both to grant their demands. In the OPM Indonesia conflict, this mechanism is an excellent mechanism in accommodating demands between the two parties who have not met the point of contact, to be able to compromise with Indonesia in adjusting its position to face an OPM party whose position is unbalanced, as well as the OPM to can consider its unbalanced position with the Government of Indonesia, so that together they can reach new agreements and are agreed by both parties.

\section{Research Methodology}

This study used qualitative methods to discuss phenomena in a descriptive, detailed and indepth manner. According to Checkel (2008), Hermann (2008), and Neumann (2008), there are three analytical techniques, namely: 1) process tracing; 2) content analysis; 3) discourse analysis. Tracing process technique is a process discussing and describing a case in a causal chain with interconnected dependent and independent variables. The independent variable chosen was the horse-trading conflict resolution mechanism and the dependent variable was the case of the Papuan separatist movement. The sources used were books, journals, newspapers and official government documents. In this article, the study also used analysis tools in the form of timelines and conflict mapping to map the actors and problems of the conflict. The study chooses both analysis tools because the study sees that both are appropriate to discuss the conflict process raised by OPM. The timeline is used in the discussion to explain the course of the conflict between the OPM and the Government of Indonesia that has taken place since 1965today. Furthermore, conflict mapping was to explain who the various parties involved in the conflict were as well as which parties contribute to the resolution. The study also referred to the conflict resolution model of Galtung where peace is not only limited to the absence of war (negative peace), but the formation of harmony of equality, the absence of all forms of violence, and the creation of social justice (positive peace).

\section{Results and Discussion}

\section{A. Historical Aspects of Free Papua Movement Establishment}

The problems of the Papua region have been happening all this time and becoming old stories that have not found a solution. This problem has been around since the beginning of the process of integration of the Papua region into Indonesian territory. There are two factors, both internal and external factors that are considered to trigger the birth of conflict between Papua and Indonesia. An internal factor from the Indonesian side was the difference of ideas between Soekarno and Muh Yamin with Moh Hatta. At the BPUPKI (The Investigating Committee for

Copyright (C) 2019. Owned by Author(s), published by Society. This is an open-access article under CC-BY-NC-SA license. 
Preparatory Works for Indonesian Independence or Badan Penyelidik Usaha-usaha Persiapan Kemerdekaan Indonesia) session, Soekarno and Muh Yamin thought that the territory of Indonesia is the entire territory of the former Dutch East Indies, including Papua. Their desire is reinforced by the fact that Papua is a region with abundant natural resources. However, Moh Hatta thought that the Papua region was an area ethnographically different from Indonesia. The population of Indonesia is largely a Polynesian population, while the population of Papua is the population of Melanesia. Moh Hatta argued that the Papua region was given the freedom to determine the status of its integration with Indonesia. However, in the BPUPKI session, Moh Hatta got fewer votes so that the decision that Papua was included in Indonesia's territorial territory after independence was determined by the Government of Indonesia.

On the other hand, the Netherlands is considered as an external party who holds the control by instilling anti-Indonesian to the people of Papua. Disputing between Indonesia and the Netherlands over the status of West Irian (including Papua) broke out after the Round Table Conference (Indonesian: Konferensi Meja Bundar or KMB). In the KMB attended by both parties, the Dutch did not recognize that West Irian was Indonesian territory. Both disputes resulted in the resolution related to West Irian to be postponed for one year. This one year delay was exploited by the Dutch to instill anti-Indonesian feelings through their politics of decolonization. The Dutch want to maintain their dominance and control of the West Irian region. This is based on their interests in West Irian, including:

1. West Irian became "Tropical Holland" for Eurasian education that could not return to the Netherlands.

2. West Iran was made a place to accommodate Dutch businessmen who chose to leave Indonesia.

3. West Irian is the basis for possible intervention if there is a collapse from Indonesia's newly established (Haris, 1999).

Encouraged by these interests, the Netherlands aggressively carried out decolonization in the West Irian region. Even in the context of preventing the fall of West Irian to Indonesia, the Netherlands also promised to give independence to West Irian as a stand-alone country. The Netherlands also carried out a series of improvements in West Irian, such as building schools, granting permits for political parties, and increasing subsidies for West Irian. The series of improvements are aimed at attracting the sympathy of the people and international parties, by showing that West Irian can stand as its own country. At that time the Dutch also held administrative control over the West Irian region.

The improvements in West Irian, particularly in the political field increased the sense of nationalism and political awareness among the people of West Irian. Coupled with the existence of several political parties, it made the people of West Irian aggressively fight for independence. Then in 1960, the people of West Irian made demands on the Dutch to give sovereignty to West Irian. The existence of these demands made the Netherlands form a body as a form of democracy in West Irian or Papua under the name Nieuw Guinea Road or the Nieuw Guniea Council. Guinea Nieuw Council is a legislative body that is useful for introducing democracy to the people of Papua. Also, the Netherlands established police and the Papua Battalion. Subsequently, on 19 October 1961, a National Committee was formed which aimed at preparing for Papuan independence. The National Committee then succeeded in producing several manifestos, among others, West Papua as the name of the country, Hai Tanahku Papua as the national anthem, the symbol of the country in the form of a Mambruk Bird, the National Flag in the form of a Morning Star, and One People One Soul as the motto. 
Flying the Morning Star flag was first carried out on December 1, 1961, and the song Hai Tanahku Papua was sung. This raising took place for approximately one week until the start of the administration of the United Nations Temporary Executive Associations (UNTEA). UNTEA itself is a UN-formed body assigned to temporarily take over leadership of the West Irian region. Indonesia and the Netherlands agreed to settle this dispute through the United Nations, although in the end no agreement was reached.

Previously, Indonesia in 1961 had called for Trikora (Tri Komando Rakyat - a strategy for mobilizing the nation) which aimed at thwarting the formation of the puppet state of Papua and raising the Indonesian flag in West Irian. The existence of Trikora was also a sign of Indonesian military operations to seize West Irian. Large-scale military conflict almost occurred after Indonesia conducted Operation Jaya Wijaya to fight the Dutch. Meanwhile, the Netherlands also formed Papuan Volunteer Corps troops who came from local volunteers and had been trained. Also, the Dutch step in bringing about anti-Indonesian feelings can be said to be successful. This was proven by the large-scale demonstration on 1 December 1962 aimed at opposing Indonesia.

On the other hand, fears of the international community, especially the United States of America (USA), commonly known as the United States (U.S.), have begun to emerge. The U.S. is afraid that Indonesia will eventually fall into communist hands due to the lack of Western support in the Papua case. The U.S. then changed its attitude from being neutral to being an active mediator of this dispute. These changes made Australia also the same to change attitudes. Australia then chose to stop cooperation with the Netherlands in 1961. Then in 1962, through the New York Agreement involving Indonesia, the U.S., the Netherlands and the United Nations, disputes over the Papua region were settled. The Netherlands then left Papua in December 1962. With the departure of the Dutch from Papua, anti-Indonesian leaders moved to the Netherlands, which eventually spearheaded the birth of the Free Papua Movement (OPM). OPM itself was born because of disappointment and a sense of not accepting the verdict of the New York Agreement. They felt cheated because in the agreement there were no figures from Papua involved. In the New York Agreement, it was stipulated that the administrative management of the Papua region be handed over to Indonesia, to further hold the Act of Free Choice (Indonesian: Penentuan Pendapat Rakyat or Pepera) to determine the status of integration of Papua with Indonesia (Premdas, 1985).

\section{B. Free Papua Movement (OPM)}

Free Papua Movement (Indonesian: Organisasi Papua Merdeka or OPM) is a separatist movement that has been established since 1963. On July 26, 1965, under the leadership of Permenas Ferry Awom, a former sergeant major in the Dutch colonial police (Papua Vrijwulinger Corps), who led a series of armed uprisings in Manokwari (Djopari, 1993). OPM is an organization consisting of three elements: group of armed units; each unit with limited territorial control with no single commander; several groups through demonstrations and protests give expression to a much more widespread sense of injustice and resentment; and a small group of leaders based abroad who try to raise awareness of Papuan issues with a view toward generating international support for independence (Institute for Policy of Conflict, 2015). Almost all of the armed members are based in Papua. However, there are some others on the border and deepening of Papua New Guinea. There are approximately three military commands, namely Goliath Tabuni with Tingginambut bases, in Puncak Jaya Regency; Puron Wena based on Lanny Jaya; Richard Hans Yoweni based on Papua New Guinea (BBC News Indonesia, 2018).

Copyright (C 2019. Owned by Author(s), published by Society. This is an open-access article under CC-BY-NC-SA license.

https://doi.org/10.33019/society.v7i2.86

87 
In OPM there are two main factions led by Terianus Aronggear, SE (1964) and Aser Demotekay (1963) (Djopari, 1991). The faction established by Aser Dmotekay was based in Jayapura and chose the path of cooperation in its struggle. Aser asked the the Government of Indonesia to grant independence to Papua following the promise of the Bible and the promise of the ancestors. The other faction was under the leadership of Terianus Aronggear based in the Manokwari area. Slightly different from the previous faction, this faction arranged political and physical opposition to the government of Indonesia. Besides, Terianus Aronggear also compiled documents to be smuggled into the United Nations. The document contains questions about the status of West Irian and a review of the New York Agreement which is considered unfair to them. Besides, the document also contains the draft independence of the state of West Papua with Markus Kaisiepo as president (Ngatiyem, 2007). However, before the document was smuggled, Terianus Aronggear was captured on May 12, 1965, in Biak.

For the Government of Indonesia, OPM is a designation for every organization or faction in Irian and also based abroad which has the goal of releasing Irian Jaya (West Papua) from the Republic of Indonesia with pro-West Papua leaders (Ngatiyem, 2007). While Viktor Kaisiepo assumed that the OPM was a faction born of struggles in Irian Jaya and West Papua. It was they who sent information to Papuan leaders in the Netherlands to both fights for the independence of West Papua. Thus, Papuan leaders in the Netherlands, such as Nicolaas Jouwe and Marcus Kaiseiepo, then formed a military and political struggle for West Papua's independence in the name of the Free Papua Movement (OPM) as a unity of the West Papua struggle (Djopari, 1993).

\section{OPM - Government of Indonesia Conflict Backgrounds}

OPM staged a series of rebellions due to several factors. One of them is motivated by dissatisfaction with the results of the Act of Free Choice (Indonesian: Penentuan Pendapat Rakyat or Pepera) which shows that Papua chose to become part of Indonesia. The decision was legally established in UN Resolution 2504, stating that there was a transfer of Papuan power into Indonesian hands (Agreement between the Republic of Indonesia and the Kingdom of the Netherlands concerning West New Guinea (West Irian), 1996). The pro-Papuan community believes that the vote does not involve the people of Papua and does not represent the interests of the people of Papua. Meanwhile, the Government of Indonesia in 1969, under Soeharto's leadership, referred to the New York Agreement, choosing 1,026 people to represent Papuans in the Pepera (Indonesian Institute of Sciences, Current Asia and the Center for Humanitarian Dialogue, 2011). For pro-Papuan people, the decision was considered cheating. The perception gap regarding Papua's integration into Indonesia is one of the triggers for separatism conflict.

After the legalization of the Pepera results were administratively integrated into the Indonesian territory. Separatist conflict persists due to the decision of the central government which is considered detrimental to the people of Papua. One of them is the application of Papua as a Military Operations Area (Indonesian: Daerah Operasi Militer or DOM). The accusation of exploitation of nature also triggers separatism to continue a rebellion. The signing of a cooperation contract with U.S. based mining giant company, Freeport-McMoRan for approximately 30 years, raises the belief that Papua's natural wealth will be exploited by external parties. The transmigration program by the government is also considered to be detrimental to them. The existence of this transmigration program makes the Papua region more dominated by parties who are not native Papuans. Papua's economic and social inequalities are increasingly felt by the people of Papua. They feel that their territory has a lot of natural wealth, but those who enjoy it are outsiders, whereas indigenous people cannot feel it. According to Soedarjanto (2000) quoted by Ngatiyem, the people of Irian Jaya (Papua) want to

Copyright (C) 2019. Owned by Author(s), published by Society. This is an open-access article under CC-BY-NC-SA license.

https://doi.org/10.33019/society.v7i2.86

88

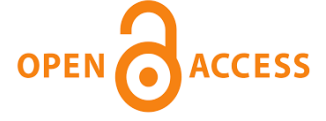


get out of the Republic of Indonesia due to 1) the unfair treatment that has been felt by the people of Irian Jaya, 2) feels abandoned, 3) the aspirations of the people of Irian Jaya are not accommodated (Ngatiyem, 2007). Some of the reasons that have been mentioned are the basis of why the OPM is resisting causing some conflicts.

To achieve its objectives, the OPM staged a series of rebellions against the Government of Indonesia. They also garnered international support. The form of resistance by OPM has also changed. During the early days of the resistance, armed conflicts often occurred between the OPM and the Government of Indonesia. But over time, the OPM began to include the practice of diplomacy in resisting Indonesia.

According to MT Arifin (2007), quoted by Ngatiyem, rebellions by OPM are divided into physical and non-physical rebellions. Physical uprising uses weapons in resistance; Nonphysical rebellion raises flags and other statements (Agreement between the Republic of Indonesia and the Kingdom of the Netherlands concerning West New Guinea (West Irian), 1996). OPM rebellion and resistance occur sporadically under different leaders. To make it easier to understand the course of the conflict and rebellion carried out by the OPM, the study divided the uprising period into three periods, namely: 1) the pre-integration period of West Irian and Indonesia (1965), 2) the post-integration period of West Irian and Indonesia under the leadership of Soeharto, and 3) the collapse of the New Order government (Indonesian: Orde Baru or ORBA) (1998) and the enactment of Special Autonomy to the present. To facilitate readers' understanding, the study uses a timeline to explain how the OPM resisted in the three periods mentioned.

Figure 1

OPM Rebellion Timeline

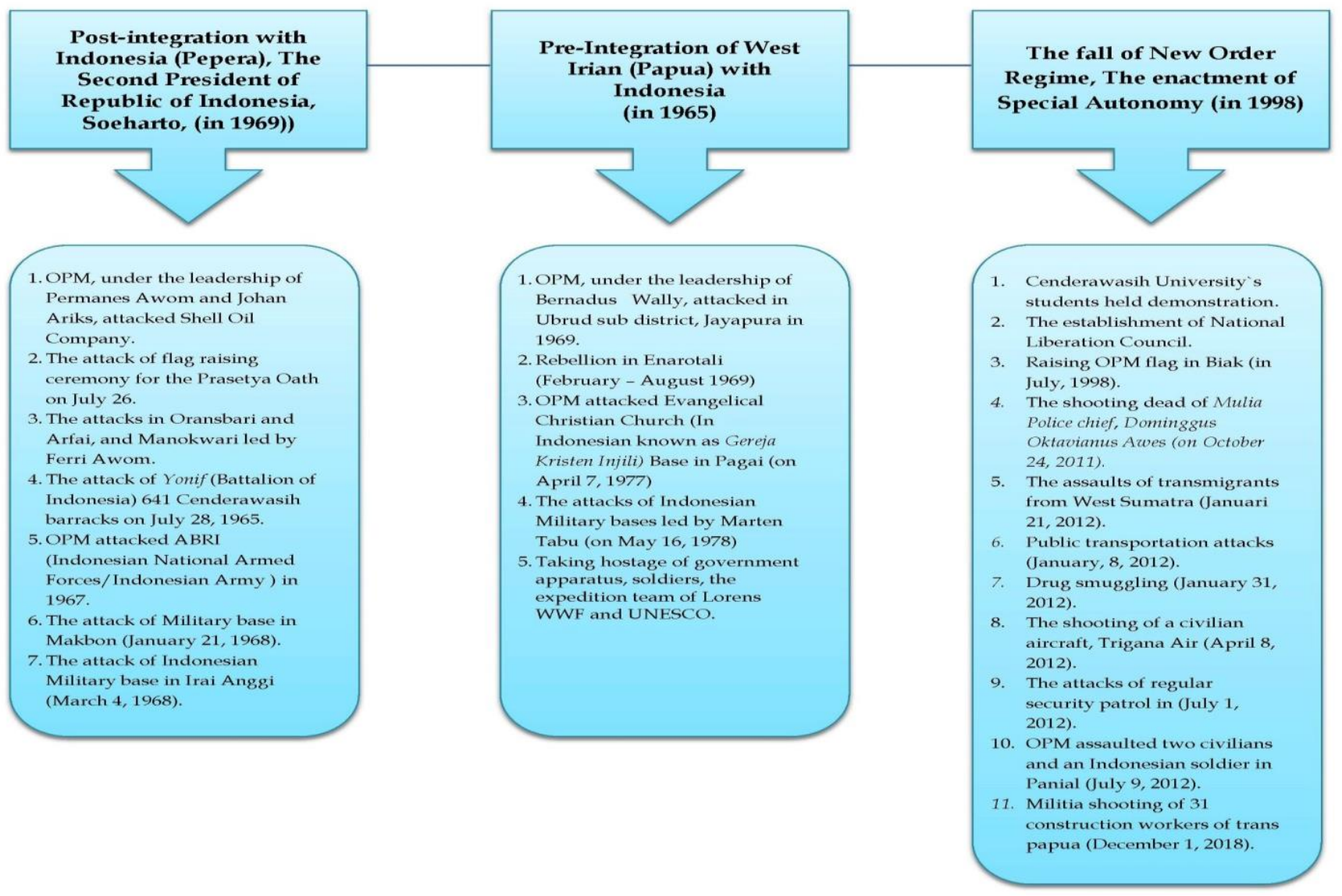

Copyright ( 2019. Owned by Author(s), published by Society. This is an open-access article under CC-BY-NC-SA license. https://doi.org/10.33019/society.v7i2.86 
If we look closely, there is a change like the resistance made by the OPM. At the beginning of the fight more armed contact and based on the desire for independence. However, after the existing integration process, although resistance was still traditional in the use of weapons, the background to the resistance began to increase. Disappointment and economic and social injustice make the people of Papua continue to aggressively carry out resistance despite being integrated with Indonesia.

After the collapse of the ORBA and the introduction of Special Autonomy, there was a significant shift in resistance. Resistance is not merely using weapons but has also entered the stage of using diplomacy, proven by the establishment of the National Liberation Council. Besides, the motives of resistance tend to be more economic aspects than the nationalist sense of Papua itself. This can be seen because, after the enactment of Special Autonomy, resistance by OPM was not only directed at Indonesian National Armed Forces known as ABRI or TNI. From the existing figure, the targets of attacks by OPM in the period after the collapse of the New Order were also civilians. Besides, OPM resistance has also begun to target the commercial sector such as civilian aircraft attacks.

All changes in the forms of demands and patterns of rebellion by OPM must be an important reference for the government in determining policy. The resolution offered must adapt to the facts, that the peace that is created is not just the elimination of war, but the elimination of all forms of injustice.

\section{Previous mechanism in Resolving Indonesia-OPM Conflict}

The OPM conflict begins with conflicts between groups within the OPM organization and OPM conflicts with community groups in Papua itself. Therefore, in the early days of the rebellion, the Government of Indonesia acted as a third party handling the conflict between these groups. According to Djopari's study (1991), in 1963 and 1964 there were divisions in the OPM military faction due to differences in pro-Western political orientation and neo-Marxist or socialist orientation from OPM political leaders. Besides, before the OPM developed into a separatist organization, the OPM movement began with an armed attack, vandalism, hostagetaking, demonstrations and raising the West Papuan flag by the Arfak tribe in Manokwari and subsequently extending to various districts in Irian Jaya. Military divisions caused the military of the OPM to weaken so that their rebellion was successfully crushed by the government of Indonesia which at that time was carried out by the Armed Forces of Republic of Indonesia (Indonesian: Angkatan Bersenjata Republik Indonesia or ABRI).

At that time, the Government of Indonesia considered the OPM's actions as an effort to separatism that violated Indonesian law and sovereignty, so that the Government of Indonesia felt entitled to take up arms resistance. Various actions taken as part of separatism are regulated in Chapter I of Second Book: Crimes of the Criminal Code, where the act of rebellion according to Article 108 includes crimes against government, and separatist movements according to Article 106 are classified as treason attempts. The efforts of armed attacks between ABRI and OPM have added to the death penalty.

Furthermore, it will begin to realize the problem of historical inequality, welfare issues, and the problem of Papuan identity which subsequently brought the Government of Indonesia in 1971-1973 in the continued handling of this conflict by means other than militaristic namely the nationalization of cultural, social, economic and political aspects, and leaving their original aspects with the aim of creating a society in accordance with the practice of Pancasila (Five Principles, the Indonesian state philosophy) and the 1945 Constitution, which is just and prosperous. However, this effort seems to build the perception of the people of Papua that the

Copyright (C) 2019. Owned by Author(s), published by Society. This is an open-access article under CC-BY-NC-SA license.

https://doi.org/10.33019/society.v7i2.86

90 
identity of their culture is uncivilized and underdeveloped by Indonesia, thus triggering the perception of their cultural divide from Indonesia (Sugandi, 2008).

Until 1999 the government conducted the division of Irian Jaya through Republic of Indonesia Law number 45 of 1999 by President Habibie with the formation of the Province of West Irian Jaya, Central Irian Jaya Province, Mimika Regency, Puncak Jaya Regency, and Sorong municipality. The expansion was carried out to improve governance and foster community in the area to facilitate the strengthening of the integration of Papua as part of the Unitary State of the Republic of Indonesia. But again, Papuans rejected this policy because they considered that making this policy did not involve their voices.

This refusal further encouraged the formation of regional autonomy in Papua, where, through MPR Decree No. IV/MPR/1999, an autonomous framework was discussed which sought to meet the demands of the Papuan people, namely to respect cultural differences and the social life of the Papuan people. By beginning to follow up on claims for differences in these aspects, finally Law Number 21 of 2001 concerning Special Autonomy for the Province of Papua was legalized. This policy provides the opportunity for the people of Papua to develop the governance of their territories and improve the welfare of their communities by the obligations and rights of Indonesian citizens while respecting the basic values of the indigenous Papuan population. This policy also returns the name Irian Jaya to Papua. The Government of Indonesia has high hopes in the implementation of this policy, including as an effort to reduce OPM actions. However, the implementation and support of various related government institutions have also not been effective.

Including crossing these policies with other national policies that hinder the achievement of Special Autonomy (Indonesian: Otonomi Khusus or Otsus), one of which is the transmigration program to Papua. Coupled with the post-Otsus dilemma of supporting Otsus or entirely independent from Indonesia, the insecurity of Otsus itself is due to unbelief and pessimism from the people of Papua to state administrators (Kementerian Koordinator Bidang Politik, Hukum, dan Keamanan Republik Indonesia, 2016). Besides, there is a central government policy that is counterproductive to the demands or hopes of the Papuan people, one of which is a transmigration program that is rejected by indigenous Papuans and has an impact on horizontal conflict. The transmigration program to Papua was finally stopped by the government in 2000 (Kompas.com, 2015). Government efforts have not yet demonstrated success in dealing with this conflict. Until the armed action in 2018, the the government of Indonesia through the TNI and POLRI (the National Police) still had to deploy troops to deal with attacks carried out against civilians and police in Papua.

In the 2000s, in addition to the militaristic efforts that were still being made, the government also returned to pay attention to the economic, educational, health, socio-cultural, and political aspects of Papua which were still less than optimal. Based on the study from Indonesian Institute of Sciences (Indonesian: Lembaga Ilmu Pengetahuan Indonesia or LIPI) in 2008, the government began to focus on building infrastructure connectivity as an effort to fulfill human rights and other aspects (Kedeputian Bidang Ilmu Pengetahuan Sosial dan Kemanusiaan, LIPI, 2008). 
Figure 2

Indonesia - OPM Conflict Mapping

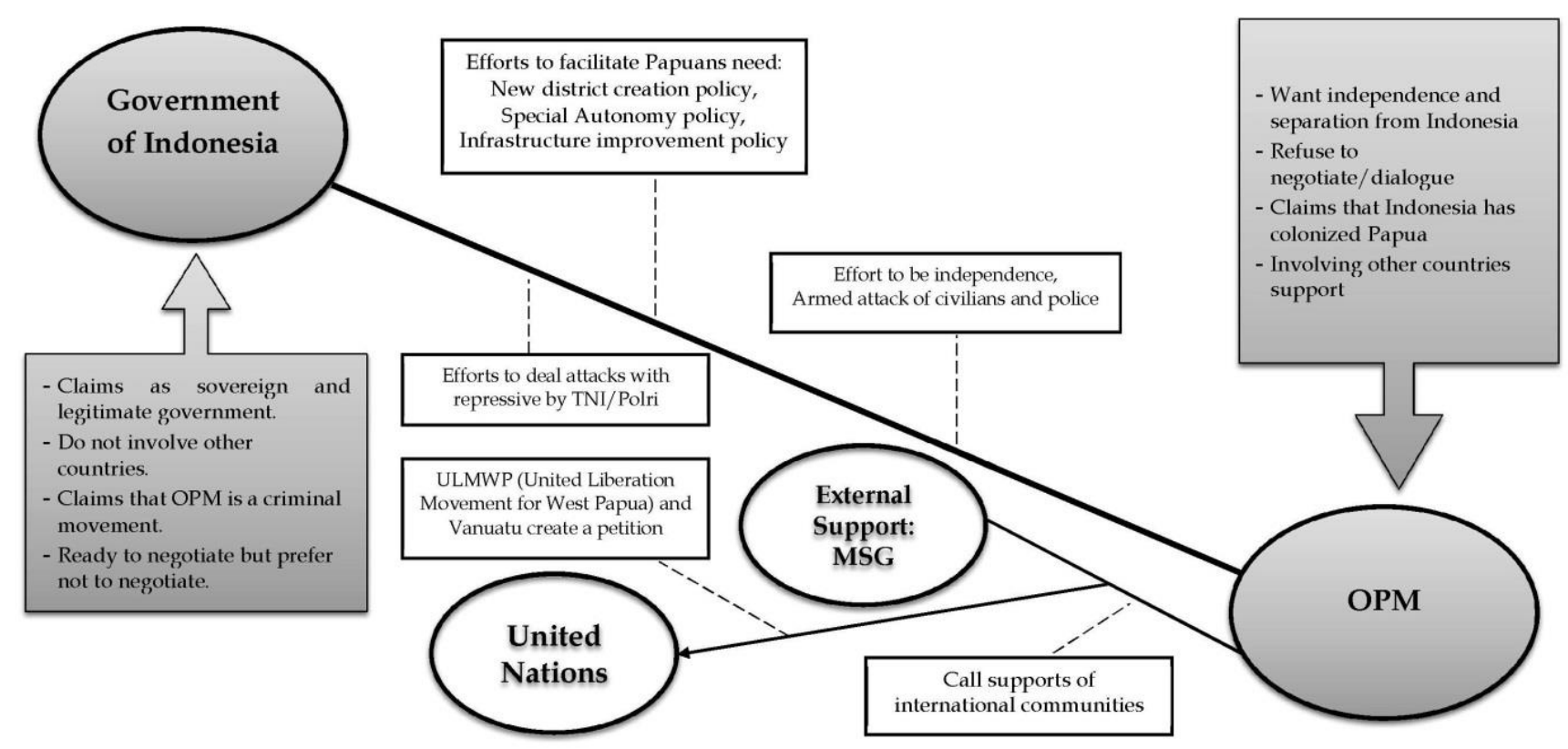

In the course of this conflict, external parties were involved. OPM based in the Pacific, the United States and Europe are trying to garner support from the international community for its independence (BBC News Indonesia, 2018). The movement from the military faction, the OPM ULMWP (United Liberation Movement for West Papua) also submitted a petition to the United Nations intending to be able to re-enter the UN Decolonization Committee list. The petition was signed by 1.8 million with a percentage of $95.77 \%$ coming from indigenous people of West Papua (Institute for Policy of Conflict, 2015). The submission to the UN was also assisted by the Vanuatu state, as a member of the MSG (Melanesian Spearhead Group) and also garnered support from other MSG countries by emphasizing the value of upholding human rights and democracy (Gumilang, 2019).

Facing external support for OPM, the government of Indonesia is firm in its position as a sovereign country. With OPM's status as a rebel whose position is under the government of Indonesia, no party has the right to intervene to influence conflicts between the OPM and the the Government of Indonesia or bring it to international justice without the involvement of the the Government of Indonesia itself. Indonesia took decisive action. Vice President Jusuf Kalla in the general debate session of the $73^{\text {rd }}$ General Assembly of the United Nations stated that Vanuatu's actions violated UN principles because they did not respect the sovereignty and territorial integrity. He also stated that Indonesia would not remain silent in defending Indonesia's territorial integrity (Kompas.com, 2018).

In July 2019, the efforts of the OPM figure in the U.K. Benny Wenda succeeded by getting the recognition of the Oxford City Council, England who gave the 'Freedom of Oxford' award to Benny Wenda. The Government of Indonesia through the Ministry of Foreign Affairs in responding to this expressed strong condemnation and considered the lack of understanding of the awardees seen by Benny Wenda's actions as a separatist figure. The support of the Oxford City Council is considered by the Government of Indonesia to be meaningless given that the 
British Government has been consistent to support the sovereignty and integrity of the Republic of Indonesia (Sekretariat Kabinet Republik Indonesia, 2019).

\section{E. The Use of Horse-Trading in Conflict Resolution}

To analyze conflicts using this mechanism, it must be known in advance what the demands of each party are. However, in the context of resolving internal conflicts between the Government of Indonesia and separatist groups in Papua, it is necessary to find a meeting point on what issues can be traded, certainly an issue that is worth it for the two parties to reach an agreement. Some issues have developed in Papua that reacts to the emergence of Papuan public dissatisfaction, including the problem of optimizing public services, the issue of human development that still pays attention to its cultural values, infrastructure development, political justice, racism issues, and so on still in the corridor of national discourse and not separatism. The Papuans also need to involve a variety of stakeholders, including local governments in Papua, both provincial and district, mass organizations, indigenous communities, community leaders, youth leaders, and so on. They are groups outside the Papuan separatist movement that can engage in constructive dialogue with the central government to re-establish harmonious relations with the central government.

The conflict resolution mechanism adopted by the Government of Indonesia shows that Indonesia's main interest is to defend Papua as part of the Unitary State of the Republic of Indonesia, stop attacks carried out by the OPM, and not give the OPM the slightest opportunity to conduct a referendum. It can be seen in Figure 2, the Government of Indonesia is a party with greater power than OPM. On the other hand, the OPM based on history and culture does not recognize the Papua region as part of the Unitary State of the Republic of Indonesia, so the OPM demands a referendum on the Government of Indonesia and in any case continues to carry out separatist efforts.

The main demands of each party are equally large and contradictory. In the horse-trading mechanism, to resolve the conflict, demands that are difficult to find a way to meet must be set aside first. However, because there is a power of attorney on one side, the Government of Indonesia, Indonesia can't give a referendum to OPM. The issue of sovereignty and national unity is essential for Indonesia.

OPM itself views the Government of Indonesia during this time colonizing Papua and taking ways that do not truly represent the people of Papua at the time of the determination of Papua as part of the Unitary State of the Republic of Indonesia. So in setting aside the goals of Indonesia which so far have been viewed by Papua as such, from this view, Indonesia should be able to prove that Indonesia is a government that embraces and develops Papua, not colonizing Papua. The complexity of this situation means demanding that Indonesia be able to meet the needs of OPM, at least in proportion to what OPM gets when it breaks away.

OPM's view that Papua was colonized is motivated by differences and gaps between Papua and other regions in Indonesia, both in terms of culture, region, ethnicity, etc. The government of Indonesia has taken an approach, trying to find out the root causes of this conflict, trying to find aspects of what aspects are still minimal and needed by Papua, and try to fulfill that. Efforts to embrace and respect Papua are carried out through the Special Autonomy policy. According to Law Number 21 of 2001, through Otsus, Papua has special authority recognized by the government to regulate and manage the interests of its people based on their initiatives, aspirations and basic rights of the people of Papua. This policy also regulates differences in governance in Papua with other Indonesian provinces, where there is a Dewan Perwakilan Rakyat Papua (Papuan People's Representative Council or DPRP) which is a legislative body in

Copyright (C) 2019. Owned by Author(s), published by Society. This is an open-access article under CC-BY-NC-SA license.

https://doi.org/10.33019/society.v7i2.86

93 
Papua, a governor's apparatus called the Papua Provincial Executive Board, and the existence of the Majelis Rakyat Papua (Papuan People's Assembly or MRP) which is a cultural representation indigenous Papuans. This autonomy gives Papua Province the authority over all fields of government, but is listed in the Law of the Republic of Indonesia Number 21 of 2001 Concerning Special Autonomy for the Province of Papua such authority does not include the fields of foreign politics, security, defense, monetary and fiscal, religion, justice, as well as certain authorities. The Papua Province can only carry out cooperation or international agreements by statutory regulations. Special Autonomy Funding is still being carried out until 2018. From 2001 to 2017, funds disbursed for Papua and West Papua amounted to 67 trillion rupiah. Meanwhile, according to Presidential Regulation No. 129 of 2018, for 2019 the government allocated 5.850 trillion rupiah for Papua Province and 2.507 trillion rupiah for West Papua Province. Even in 2019, there was an Additional Infrastructure Fund of 2,824 trillion rupiah for Papua Province and 1,440 trillion rupiah for West Papua Province (BBC News Indonesia, 2018).

This policy along with the flushing of funds, unfortunately, did not stop the OPM referendum effort. The funds that flow have also not succeeded in bringing Papua out of poverty. Lack of empowerment from the Papuan people themselves is one factor. It is also difficult to create access for people who have per capita opinions, due to the immature work skills of the Papuan people.

The Chairperson of the MRP believes that Otsus funds have not been well-targeted. He believes that the Special Autonomy Fund has not yet maximized health, education and economic services (BBC News Indonesia, 2018). Indonesian Corruption Watch (ICW) has also received reports from the public about the misappropriation of Papuan Otsus funds by the regional political elite (tirto.id, 2018).

Based on what has already happened, what the Special Autonomy policy wants to achieve has not been successful. Though, the idea of Special Autonomy is the best effort that can be done. So, to resolve this conflict with a horse-trading mechanism, Special Autonomy must be carried out well, starting from the calculation of the Government of Indonesia, as well as support from the Papuan people themselves, and overcoming existing obstacles.

If the Government of Indonesia has provided the best policy, on the other hand, the OPM must also be able to reduce its selfishness. Perhaps OPM can't reduce its demands to be separated from Indonesia. However, reducing egoism by being open and accepting the efforts of the Government of Indonesia can facilitate the peaceful resolution of conflicts. At least without involving armed action and violence against civilians. Only in the horse-trading mechanism, after both parties agree to reduce their respective demands, can a compromise be made through dialogue between the two parties, to jointly make new decisions.

So far, there has never been a dialogue between the Government of Indonesia and OPM. The importance of conducting a dialogue between the TNI and OPM has been planned since the era of President Susilo Bambang Yudhoyono's administration, but it was never carried out until the end of his leadership. Likewise in the era of President Jokowi. Through the TNI, it is expected that there will be a dialogue with OPM to better understand OPM's true desires. Coordinating Minister for Political, Legal and Security Affairs of the Republic of Indonesa, Wiranto in 2019 stated that the dialogue between the government and the armed group OPM was not possible. First, the position is not parallel between the armed groups and the government, in the government opinion, the armed group of OPM is a criminal group that must be captured or resolved. Second, there will be doubts from the OPM whether in the dialogue OPM can truly express their wishes and the TNI will accept it, or whether this dialogue is

Copyright (C 2019. Owned by Author(s), published by Society. This is an open-access article under CC-BY-NC-SA license.

https://doi.org/10.33019/society.v7i2.86

94 
supported by the central government. Then the third, there is a tendency for the OPM to refuse to engage in dialogue, because they have been seen as enemies of the government, and can be trapped or captured by the government of Indonesia at any time on charges of separatism (Tempo.co, 2019).

As a suggestion, according to the horse-trading mechanism, the dialogue still needs to be done to result a compromise. However, the dialogue that must be carried out according to this mechanism is between two balanced actors. So in the case between the Government of Indonesia and OPM, the dialogue between the two parties must make some adjustments. OPM status until now is a rebel or insurgent whose responsibility is under the government of Indonesia. This status does not allow OPM to adjust its position to the level of a country and this position will certainly never be expected by the Government of Indonesia. So, in this case, the Government of Indonesia is the party in the dialogue that must adjust its position. The government of Indonesia can reduce the level of actors who engage in dialogue. Lowering the level of the actor in question is reducing in terms of the quantity and 'attributes' of the military. Because the government dialogues generally involve various lines of government and are very state-centric. A similar dialogue was held by the Government of Indonesia in negotiations to free the citizens of the Abu Sayyaf group. The Government of Indonesia sends negotiators who can discuss with the hostage-takers and utilize the assistance of non-state actors who are close to people in the Southern Philippines. In this case, the Government of Indonesia relies on parties who are more likely to be accepted by the hostage-takers by also considering the communication and information needed to negotiate with the hostage-taker (Istikharoh, 2017). This can be done by the Government of Indonesia in conducting a dialogue with OPM by deploying group or individual actors representing the government but on the other hand, is also an expert in negotiations and has enough information to be able to convey Indonesia's demands and hear demands from OPM.

In this dialogue, it is also important to pay attention to the deepest aims and objectives of the OPM, which so far should have been fulfilled by the government of Indonesia but has been neglected. Because in 2015 a dialogue between the armed groups of the OPM and the Governor of Papua proved to be successful in representing demands that the government of Indonesia could fulfill. In the dialogue, the leadership of the West Papua National Liberation Army - Free Papua Movement (Indonesian: Tentara Pembebasan Nasional Papua Barat Organisasi Papua Merdeka or TPNPB-OPM) gave a verbal and written request, so that the central government could enter the Puncak Jaya region and carry out development in the area. At that time, Papua Governor Lukas Enembe said he would fulfill the request on condition that the TPNPB-OPM stops the violence in the area, and return the TNI/POLRI weapons that had been confiscated. So basically, it is not impossible to have a dialogue between the Government of Indonesia and the OPM, with a large record, the two parties can minimize the egoism between the two, to further find each other's desires that can be fulfilled together by both parties (Republika.co.id, 2015).

Another thing to note is the diversity of the OPM itself. The dialogues that were held only represented certain groups of OPM. Meanwhile, this dialogue can successfully eradicate all conflicts, to bring together all OPM parties so that all demands are represented and conveyed as a whole. In addition to the Indonesian side sending qualified actors to dialogue, as well as OPM, this dialogue must involve OPM as a whole, given the diversity of OPMs and their interests, either by involving all the representatives of each OPM, and or designating a representative who can represent all OPMs. 
In addition to changing the actors involved in a dialogue, the Government of Indonesia must also emphasize the results it wants to achieve. The efforts made by the government only focus on development in Papua. Whereas the aspects involved in efforts to restore the situation in Papua are not just development. The government seems to forget other aspects such as the existence of violence, discrimination and other forms of inequality. In this case, this study emphasizes that in addition to including the development agenda, the dialogue must be oriented towards meeting the basic human needs, including the elimination of all forms of violence and injustice in Papua. As mentioned by Galtung that conflict can occur due to the unfulfillment of basic human needs.

Figure 3

Human Basic Needs according to Johan Galtung

\begin{tabular}{|c|c|c|}
\hline & BASIC NEEDS & SOCIO-POLITICAL PROBLEMS \\
\hline \multirow[t]{2}{*}{ I. } & THE MOST BASIC NEED & \\
\hline & life, survival & violence - security, absence of violence \\
\hline \multirow[t]{3}{*}{ II. } & BASIC NEEDS & \\
\hline & $\begin{array}{l}\text { Input: } \\
\text { food, water }\end{array}$ & poverty - growth, well-being \\
\hline & $\begin{array}{l}\text { Environment protection: } \\
\text { clothes, shelter, health } \\
\text { Community: } \\
\text { education, togetherness }\end{array}$ & \\
\hline III. & $\begin{array}{l}\text { NEAR-BASIC NEEDS } \\
\text { work, creativity } \\
\text { freedom, mobility } \\
\text { politics, participation }\end{array}$ & repression - human rights, social justice \\
\hline \multirow[t]{2}{*}{ IV. } & $\begin{array}{l}\text { RELATION TO NATURE } \\
\text { partnership }\end{array}$ & $\begin{array}{l}\text { environmental deterioration } \\
\text { ecological balance }\end{array}$ \\
\hline & & $\begin{array}{l}\text { - depletion problem } \\
\text { - pollution problem } \\
\text { - population problem }\end{array}$ \\
\hline
\end{tabular}

Source: (Galtung, Theories of Conflict: Definitions, Dimensions, Negotiations, Formations, 1958)

In the figure 3, Galtung mentioned that basic human needs are not limited to clothing, food, and shelter. We can see that the most basic needs for humans according to Galtung are related to life and survival. Besides, there are also human needs related to work, creativity, freedom, politics, and participation. In this case, if these needs are not met then violence will occur. The dialogues conducted by the government tend to be on the fulfillment of development-oriented needs, such as repairing road facilities, providing grants for regional development, and so on. This is not wrong, but if we look at the figure above, then the agenda for government dialogue must also be changed. The Government of Indonesia must also emphasize the elimination of violence, discrimination, and opportunities for the people of Papua. As we also know, the pattern of resistance from the Papuan separatist movement has also changed. Their call was no longer just about equitable development, but about racial and ethnic discrimination. In this 
case, the government must be observant of responding to these calls. The government must be vocal in including the agenda of eliminating discrimination and injustice in dialogues with separatist movements in Papua.

The government can enter the agenda by using Galtung's approach to the typology of violence.

Table 1

Typology of Galtung violence

\begin{tabular}{|c|c|c|c|c|}
\hline & $\begin{array}{l}\text { Survivel } \\
\text { Needs }\end{array}$ & $\begin{array}{l}\text { Well-Being } \\
\text { Needs }\end{array}$ & $\begin{array}{l}\text { Identity } \\
\text { Needs }\end{array}$ & $\begin{array}{l}\text { Freedom } \\
\text { Needs }\end{array}$ \\
\hline \multirow[t]{3}{*}{ Direct Violence } & Killing & Maiming & Desocialization & Repression \\
\hline & & Siege, Sanctions & Resocialization & Detention \\
\hline & & Misery & Secondary Citizen & Expulsion \\
\hline \multirow[t]{2}{*}{ Structural Violence } & Exploitation A & Exploitation B & Penetration & Marginalization \\
\hline & & & Segmentation & Fragmentation \\
\hline
\end{tabular}

Source: (Galtung, Cultural Violence, 1990)

According to the typology of Galtung violence, there is direct violence and structural violence. Direct violence includes murder, siege, misery, decolonization, reconciliation, repression, detention, and explosion, whereas, structural violence includes exploitation, penetration, segmentation, marginalization, and fragmentation. In the table, Galtung also distinguishes four classes of basic needs, namely: survival needs, well-being needs, identity needs, and freedom needs. In this case, the Government of Indonesia must include an agenda to eliminate all forms of violence in Papua. The study of violence cannot be separated from the study of peace. Therefore, to create peace, we must also know what violence is in Papua. In addition to meeting basic needs, aspects of identity and freedom need guarantees provided by the government.

In carrying out dialogue it also needs to be stressed again important aspects related to the nature of the dialogue that is persuasive and abandons military methods. Referring to the adjustment of the level of actors who are derived, also the dialogue strategy with the approach to eliminate the typology of violence in Papua as explained earlier.

In some international conflicts, the horse-trading mechanism is applied in conflicts that involve power between countries and involve the interests of various actors or issues. As in state border conflicts Iraq and Iran, also weapons and nuclear negotiations the United States and the Soviet Union (Wallensteen, 2015).

This mechanism results in a new decision which can be accepted by both parties. In achieving its success, this mechanism requires good cooperation between the two parties. In essence, this mechanism leads to a peaceful resolution of conflicts. Conflict resolution in international relations is an approach based on insights generated from contemporary peace studies. Where to reflect on the conflicts of war and weapons that occurred in the past, and find out the causes of violence to find ways to reduce or eliminate them in the future. In conflict resolution studies, the mechanism allows resolving an armed conflict in certain ways which ends with a peace agreement (Wallensteen, 2015). Thus, applying the usual mechanism applied in conflicts between diverse forces and interests of the country, the value of horse-trading study mechanism has the opportunity to produce a settlement with the peace agreement as well, because a new decision is made and both parties share each other. 


\section{Conclusions}

The conflict occurred between the Government of Indonesia and Free Papua Movement is a conflict with the roots of complex problems, ranging from historical problem, ideology, to a sense of injustice received by Papuan. The opposition happens was not only to liberate Papua, but also to strive for social and economic justice. Conflict resolution has been carried out by both parties is still considered ineffective. The dialogue between the two parties is the best way to resolve the conflict. The horse-trading is a dialogue mechanism that is more effectively applying as a solution for conflict resolution so both of them can deliver their objectives openly. Various adaptations are also needed in conducting dialogue; changing the actor level and the agenda is an important substance for the Government of Indonesia to achieve the piece. Also, commitment to conducting dialogue must be fulfilled by both parties to create an expected conflict resolution.

\section{References}

BBC News Indonesia. (2018, 12 13). Organisasi Papua Merdeka yang menuntut pemisahan Papua dari Indonesia, apa dan siapa mereka? Retrieved 4 26, 2019, from https://www.bbc.com: https://www.bbc.com/indonesia/indonesia-46539502

BBC News Indonesia. (2018, 11 22). Puluhan triliun dana otonomi khusus dialirkan, mengapa masih ada tuntutan 'Papua merdeka'? Retrieved 5 12, 2019, from https://www.bbc.com: https://www.bbc.com/indonesia/indonesia-46289211

Checkel, J. T. (2008). Process Tracing. In: Klotz A., Prakash D. (eds) Qualitative Methods in International Relations. Research Methods Series. London: Palgrave Macmillan.

Djopari, J. R. (1991). Pemberontakan Organisasi Papua Merdeka: Suatu Studi Kasus Tentang Integrasi Politik Di Irian Jaya Dari Tahun 1964 Sampai Dengan Tahun 1984.

Djopari, J. R. (1993). Pemberontakan Organisasi Papua Merdeka. Jakarta: PT Gramedia Widiasarana Indonesia.

Gumilang, P. (2019, 1 29). Petisi Referendum Papua di PBB dan Posisi Tawar untuk Jakarta. Retrieved 29, 2019, from https://www.cnnindonesia.com: https://www.cnnindonesia.com/nasional/20190128185424-32-364551/petisi-referendumpapua-di-pbb-dan-posisi-tawar-untuk-jakarta

Galtung, J. (1958). Theories of Conflict: Definitions, Dimension, Negotiations, Formations. New York: Columbia University.

Galtung, J. (1990). Cultural Violence. Journal of Peace Research, 27(3), 291-305.

Hadi, S. (2007). Disintegrasi Pasca Ordebaru; Negara, Konflik Lokal dan Dinamika Internasional. Jakarta: Yayasan Obor.

Hadi, R. P. (2016). Tantangan Keamanan Nasional Indonesia dalam Menyikapi Transformasi Separatisme dan Cyberprotest di Papua. A Joint Seminar on Public and International Affairs UUM - UNAIR. Universiti Utara Malaysia.

Haris, S. (1999). Indonesia Diambang Perpecahan. Jakarta: Erlangga.

Hermann, M. G. (2008). Content Analysis. In: Klotz A., Prakash D. (eds) Qualitative Methods in International Relations. Research Methods Series. London: Palgrave Macmillan.

Istikharoh, A. (2017). Diplomasi Indonesia dalam Pembebasan Sandera di Luar Negeri Studi Kasus: Diplomasi Total dalam Pembebasan WNI Sandera Abu Sayyaf pada Maret-April 2016. Journal of International Relations, 3(3), 1-8.

Institute for Policy of Conflict. (2015). The Current Status of the Papuan Pro-Independence Movement. IPAC Report No. 21.

Copyright (C 2019. Owned by Author(s), published by Society. This is an open-access article under CC-BY-NC-SA license.

https://doi.org/10.33019/society.v7i2.86

98 
Kamlian, J. A. (2011). Ethnic and Religious Conflict in Southern Philippines: A Discourse on Self-Determination, Political Autonomy, and Conflict Resolution. Global \& Strategis, 1-13.

Kedeputian Bidang Ilmu Pengetahuan Sosial dan Kemanusiaan. (2008). Papua Road Map. Jakarta: Lembaga Ilmu Pengetahuan Indonesia (LIPI).

Kementerian Koordinator Bidang Politik, Hukum, dan Keamanan Republik Indonesia. (2016, 2 18). Otonomi Khusus Provinsi Papua dan Provinsi Papua Barat: Peluang, Tantangan, dan Harapan. Retrieved 5 11, 2019, from https://polkam.go.id: https://polkam.go.id/otonomikhusus-provinsi-papua-dan-provinsi-papua-barat-peluang-tantangan-dan-harapan/

Kompas.com. (2015, 7 6). Upaya Hentikan Transmigrasi ke Papua Sudah Dilakukan 15 Tahun Lalu. Retrieved 5 11, 2019, from https://nasional.kompas.com: https://nasional.kompas.com/read/2015/06/07/15520261/Upaya.Hentikan.Transmigras i.ke.Papua.Sudah.Dilakukan.15.Tahun.Lalu

Kompas.com. (2018, 11 29). Wapres Kalla: Indonesia Tak Akan Diam jika Vanuatu Terus Mengusik Papua. Retrieved 5 11, 2019, from https://nasional.kompas.com: https://nasional.kompas.com/read/2018/09/28/16534471/wapres-kalla-indonesia-takakan-diam-jika-vanuatu-terus-mengusik-papua

Lembaga Ilmu Pengetahuan Indonesia, Current Asia dan the Centre for Humanitarian Dialogue. (2011). Pengelolaan Konflik di Indonesia: Sebuah Analisis Konflik di Maluki, Papua, dan Poso. Geneva: Center for Humanitarian Dialogue.

Neuman, W. L. (2006). Chapter 6: Qualitative and Quantitative Research Designs. In Social Research Methods: Qualitative and Quantitative Approaches.

Ngatiyem. (2007). Organisasi Papua Merdeka 1964-1998 (Studi Tentang Pembangunan Stabilitas Politik di Indonesia). Skripsi Program Sarjana Keguruan dan Ilmu Pendidikan, Universitas Sebelas Maret.

Premdas, R. R. (1985). The Organisasi Papua Merdeka in Irian Jaya: Continuity and Change in Papua New Guinea's Relations with Indonesia. Asian Survey 25(10), 1055-1074.

Republika.co.id. (2015, 10 13). Lakukan Dialog, Ini Permintaan OPM pada Indonesia. Retrieved 5 12, 2019, from Republika.co.id: https://www.republika.co.id: https:// www.republika.co.id/berita/nasional/politik/15/10/13/nw561v335-lakukandialog-ini-permintaan-opm-pada-indonesia

Republik Indonesia. (1999). Ketetapan Majelis Permusyawaratan Rakyat Nomor IV/MPR/1999 Tentang Garis-Garis Besar Haluan Negara Tahun 1999-2004. Kitab Undang-Undang Hukum Pidana. Jakarta: Sekretariat Jenderal MPR RI.

Republik Indonesia. (1999). Peraturan Presiden Republik Indonesia Nomor 129 Tahun 2018 Tentang Rincian Anggaran Pendapatan dan Belanja Negara Tahun Anggaran 2019. Jakarta: Sekretariat Negara.

Republik Indonesia. (1999). Undang-Undang Republik Indonesia Nomor 45 Tahun 1999 Tentang Pembentukan Propinsi Irian Jaya Tengah, Propinsi Irian Jaya Barat, Kabupaten Paniai, Kabupaten Mimika, Kabupaten Puncak Jaya, dan Kota Sorong. Lembaran Negara Republik Indonesia Tahun 1999 Nomor 173. Jakarta: Sekretariat Negara.

Republik Indonesia. (2001). Undang-Undang Republik Indonesia Nomor 21 Tahun 2001 Tentang Otonomi Khusus Bagi Provinsi Papua. Lembaran Negara Republik Indonesia Tahun 2001 Nomor 135. Jakarta: Sekretariat Negara.

Safitri, N. (2012). Masalah Sosial dan Konflik Masyarakat Adat Papua dengan PT Freeport Indonesia. Perspektif, 1(1).

Sefriani. (2003). Separatisme dalam Perspektif Hukum Internasional: Studi Kasus Organisasi Papua Merdeka. Jurnal Fakultas Hukum UII, 26(47).

Copyright (C 2019. Owned by Author(s), published by Society. This is an open-access article under CC-BY-NC-SA license. 
Sekretariat Kabinet Republik Indonesia. (2018, 12 10). APBN 2019: Pemerintah Alokasikan Rp20,979 Triliun untuk Otonomi Khusus Aceh, Papua, dan Papua Barat. Retrieved 5 11, 2019, from https://setkab.go.id: https://setkab.go.id/apbn-2019-pemerintah-alokasikanrp20979-triliun-untuk-otonomi-khusus-aceh-papua-dan-papua-barat/

Sekretariat Kabinet Republik Indonesia. (2019, 7 18). Pemerintah Kecam Pemberian Award Dewan Kota Oxford Kepada Tokoh OPM. Retrieved 7 25, 2019, from https://setkab.go.id: https://setkab.go.id/pemerintah-kecam-pemberian-award-dewan-kota-oxford-kepadatokoh-opm/

Sugandi, Y. (2008). Analisis Konflik dan Rekomendasi Kebijakan Mengenai Papua. Jakarta: FriedrichEbert-Stiftung (FES).

Sugiyanto, M. N. (2017). Organisasi Papua Merdeka (OPM) dalam Perspektif Subjek Hukum Internasional. Makassar: Universitas Hasanuddin.

Suratman, Y. P. (2017). The Internal Conflict Taxonomy in Indonesia That Leads to Proxy War. Jurnal Pertahanan \& Bela Negara, 7(1).

Tempo.co. (2019, 2 14). Pertemuan Dialogis TNI dan OPM. Retrieved 5 12, 2019, from https://kolom.tempo.co: https://kolom.tempo.co/read/1175459/pertemuan-dialogis-tnidan-opm

Tirto.id. (2018, 7 5). ICW Akui Terima Banyak Laporan Penyelewengan Dana Otonomi Khusus. Retrieved 5 12, 2019, from https://tirto.id: https://tirto.id/icw-akui-terima-banyaklaporan-penyelewengan-dana-otonomi-khusus-cNAa

United Nations. (1996). Agreement between the Republic of Indonesia and the Kingdom of the Netherlands concerning West New Guinea (West Irian). United Nations General Assembly Resolution 2504. New York: United Nations General Assembly.

Viartasiwi, N. (2018). The Politics of History in West Papua-Indonesia Conflict. Asian Journal of Political Science, 26(1), 141-159.

Wallensteen, P. (2015). Understanding Conflict Resolution. London: Sage.

\section{About The Authors}

1. Sekar Wulan Febrianti is a student of Department of International Relations, Padjadjaran University, West Java, Indonesia. E-Mail: sekar17002@mail.unpad.ac.id.

2. Ajeng Sekar Arum is a student of Department of International Relations, Padjadjaran University, West Java, Indonesia. E-Mail: ajeng17001@mail.unpad.ac.id.

3. Windy Dermawan, obtained his Ph.D at Padjadjaran University, West Java, Indonesia, 2018. The author is an Assistant Professor at Department of International Relations, Padjadjaran University, West Java, Indonesia. E-Mail: windy.dermawan@unpad.ac.id.

4. Akim, obtained his Ph.D at Padjadjaran University, West Java, Indonesia, 2017. The author is an Assistant Professor at Department of International Relations, Padjadjaran University, West Java, Indonesia. E-Mail: akim@unpad.ac.id.

Copyright (C 2019. Owned by Author(s), published by Society. This is an open-access article under CC-BY-NC-SA license. https://doi.org/10.33019/society.v7i2.86 